the director has endeavoured to recover specimens of these instruments and also the register of observations. Unfortunately, he has found no records and none of the original vases. But he has unearthed three copies of the pluviometer. The illustration reproduced here (Fig. I) shows the instrument with the pedestal on which it stood. This instrument dates back to 1770. The three large Chinese characters declare that it is an instrument to measure rain, and the seven smaller give the date of its construction, in Chinese reckoning. Several pillars have been found without pluviometers attached, and one is particularly interesting, as a long Chinese inscription is engraved upon it, and though some of the characters have been obliterated by time, enough remains to connect it with the original order of King Sejo.

This same king erected astronomical observatories and fitted them with excellent instruments for the time. He seems to have prided himself on the possession of an automatic clepsydra, in which the hours and quarters were sounded by manikins. The general form of clepsydra seems to have consisted of four vessels at different levels, "and water poured in the highest vessel flows, passing through the intermediate ones, into the lowest, where an arrow with graduations to indicate the time in its upper part, was floated." Fig. 2 gives the general form of the instrument, but the mechanism is not well shown. Dr. Wada also reproduces a photograph of an ancient observatory, demonstrating the forward state of science of the age, about 647 A.D. It is supposed to have been used for the making of observations to correct the calendar, but there is nothing in the picture to suggest that it ever formed part of an observatory. It is simply a towerlike structure.

\section{THE ADMISSION OF WOMEN TO THE FRENCH ACADEMIES.}

$\mathrm{W}^{\mathrm{E}}$ learn from the Times of January 5 that at the recent quarterly plenary meeting of the five academies of the French Institute, the question of the eligibility of women candidates for the institute came up for consideration. It arose from the circumstance that Mme. Curie, the discoverer of radium, has been put forward as a candidate for one of the vacant seats in the Academy of Sciences. How her claims are regarded by that body may be inferred from the fact that in the list as finally submitted her name stands at the head. It is stated that at the general meeting more than 150 academicians were present, and that the proceedings, as might have been expected, "were extremely animated." Eventually the motion in favour of the admission of women was rejected by 90 votes to $5^{2}$. The institute further adopted a motion to the effect that whilst it did not presume to dictate to the separate academies, there was, in its opinion, "an immutable tradition against the election of women, which it seemed eminently wise to respect."

It remains to be seen what the Academy of Sciences will do in face of such an expression of opinion. Mme. Curie is deservedly popular in French scientific circles. It is everywhere recognised that her work is of transcendent merit, and that it has contributed enormously to the prestige of France as a home of experimental inquiry. Indeed, it is not too much to say that the discovery and isolation of the radio-active elements are among the most striking and most fruitful results of a field of investigation pre-eminently French. If any prophet is to have honour in his own country-even if the country be only the land of his adoption-surely that honour ought to belong to Mme. Curie. At the moment, Mme. Curie is without a doubt, in the eyes of the world, the dominant figure NO. 2 I $5 \mathrm{O}$, VOL. 85$]$ in French chemistry. There is no question that any man who had contributed to the sum of human knowledge what she has made known, would, years ago, have gained that recognition at the hands of his colleagues which Mme. Curie's friends are now desirous of securing for her. It is incomprehensible therefore, on any ethical principles of right and justice, that because she happens to be a woman she should be denied the laurels which her pre-eminent scientific achievement has earned for her.

There may be room for difference of opinion as to the wisdom or expediency of permitting women to embark on the troubled seas of politics, or of allowing them a determinate voice in the settlement of questions which may affect the existence or the destiny of a nation; but surely there ought to be no question that in the peaceful walks of art, literature, and science there should be the freest possible scope extended to them, and that, as human beings, every avenue to distinction and success should unreservedly be open to them.

All academies tend to be conservative and to move slowly; they are the homes of privilege and of vested interest. Some of them even incline to be reactionary. They were created by men for men, and for the most part at a time when women played little or no part in those occupations which such societies were intended to foster and develop. But the times have changed. Women have gradually won for themselves their rightful position as human beings. We have now to recognise that academies as seats of learning were made for humanity, and that, as members of the human race, women have the right to look upon them as their heritage and property no less than men. This consummation may not at once be reached, but as it is based upon reason and justice it is certain to be attained eventually.

\section{NOTES.}

AN earthquake of unusual violence occurred in Russian Turkestan at 1.25 a.m. on January 4 , or shortly after Ir p.m. on January 3 (Greenwich mean time). At Vyernyi, the chief town of the district, with more than II,000 inhabitants, the shock lasted for nearly five minutes, and has been succeeded by a large number of after-shocks. Nearly every building in the town is damaged, and all the mud-houses in the neighbourhood have collapsed. The total loss of life is unknown, but forty bodies have so far been recovered from the ruins. It is reported that the whole of the town of Prjevalsk, which is situated on the shores of lake Issik Kul, has been destroyed by the waters of the lake. The extraordinary violence of the earthquake is attested by its effects on the seismographs of distant observatories. At Pulkova, more than 2200 miles from the epicentre, practically all the instruments were thrown out of order. This was the case even in this country. At West Bromwich, the first tremors were recorded at II.35 p.m., and soon attained a range of ${ }_{15} \mathrm{~mm}$. By II.54 the range was far beyond the capacity of the instrument, and at midnight the east-west needle collapsed. The great movement continued until $\mathrm{r} 2.12 \mathrm{a} . \mathrm{m}$., and the disturbance did not end until 3.56 a.m., giving a total duration of $4^{\frac{1}{4}}$ hours. At Cardiff the maximum movement was registered at 12.14 a.m., and was so great that the instrument was deranged. At Limerick all the instruments were dismounted. The earthquake, which is one of the greatest of the last quarter of a century, is evidently a successor of that which occurred on June 9, 1887 , when Vyernyi suffered even greater injury than on the recent occasion, owing to the prevalence of stone buildings, which have since been largely replaced by wooden ones. 